\title{
Designing Institutions to Deal with Terrorism in the United States
}

\section{Citation}

Feldstein, Martin. 2008. Designing institutions to deal with terrorism in the United States.

American Economic Review 98(2): 122-126.

\section{Published Version}

http://dx.doi.org/10.1257/aer.98.2.122

\section{Permanent link}

http://nrs.harvard.edu/urn-3:HUL.InstRepos:2920114

\section{Terms of Use}

This article was downloaded from Harvard University's DASH repository, and is made available under the terms and conditions applicable to Open Access Policy Articles, as set forth at http:// nrs.harvard.edu/urn-3:HUL.InstRepos:dash.current.terms-of-use\#OAP

\section{Share Your Story}

The Harvard community has made this article openly available.

Please share how this access benefits you. Submit a story.

Accessibility 
NBER WORKING PAPER SERIES

DESIGNING INSTITUTIONS TO DEAL WITH TERRORISM IN THE UNITED STATES

\author{
Martin S. Feldstein \\ Working Paper 13729 \\ http://www.nber.org/papers/w13729 \\ NATIONAL BUREAU OF ECONOMIC RESEARCH \\ 1050 Massachusetts Avenue \\ Cambridge, MA 02138 \\ January 2008
}

The views expressed herein are those of the author(s) and do not necessarily reflect the views of the National Bureau of Economic Research.

(C) 2008 by Martin S. Feldstein. All rights reserved. Short sections of text, not to exceed two paragraphs, may be quoted without explicit permission provided that full credit, including (C notice, is given to the source. 
Designing Institutions to Deal with Terrorism in the United States

Martin S. Feldstein

NBER Working Paper No. 13729

January 2008

JEL No. H1,H56

\begin{abstract}
$\underline{\text { ABSTRACT }}$
The explosion in the 21st century of terrorist activities by Islamic radicals in the United States, Europe and Asia requires reforming the institutions for domestic counterterrorism (CT) and new international relations among individual national CT organizations. This paper discusses the institutional reforms for CT in the United States, focusing particularly on the changes in the FBI. These changes are compared with the way that the British CT activities of the MI5 and MI6 have evolved in response to terrorism in Britain. The paper also discusses the reasons why there is strong cooperation among the CT activities of all the major governments and with the United States in particular, even when those governments do not agree about military cooperation or about the use of economic sanctions.
\end{abstract}

Martin S. Feldstein

President and Chief Executive Officer

NBER

1050 Massachusetts Avenue

Cambridge, MA 02138-5398

msfeldst@nber.org 


\section{Designing Institutions to Deal with Terrorism}

\section{Martin Feldstein*}

Although local acts of terrorism have been a persistent problem in several European countries (Irish terrorists in Britain, Basque terrorists in Spain, Palestinian terrorists in Israel, etc.), global terrorism driven by radical Islam suddenly exploded in the $21^{\text {st }}$ century with attacks in Europe, in North America and in Asia. This new terrorist threat requires changes in the organization and operation of domestic counterterrorism (CT) and in the international relations among the CT activities of national governments.

Both types of change are particularly difficult to achieve. Changing the behavior of government organizations is always more difficult than it is in the private sector where change is driven by the combination of the profit motive and the pressure of competition. The inherently covert nature of surveillance and other counterterrorist activities means that international cooperation cannot be organized through traditional international institutions or in public conferences. Nevertheless change in domestic CT activities is occurring and there is evidence of strong international cooperation in dealing with terrorism.

Countering the new terrorism is enormously important to the domestic economy, to international trade, and to all of us as individuals. Potential terrorist acts include small scale attacks on local targets (e.g., bombs in shopping centers), major attacks like the nine-eleven airplane attacks in New York and Washington and the foiled attempts to blow up several planes

*Professor of Economics, Harvard University, and President of the National Bureau of Economic Research. This paper was prepared for presentation at a session on "Current and Future Institutions for the World Economy" at the annual meeting of the American Economic Association on January 4, 2008. For more extensive discussions of this subject, see Richard Posner Countering Terrorism (2007) and earlier books by that author. 
flying from London to New York, dirty bombs that combine radioactive material and conventional explosives, cyberterrorism that could shut down communication and transportation networks, bioterrorism that could cause widespread disease, attacks on ports and other key infrastructure, and the explosion of even a small nuclear device that could kill millions of people and destroy a major part of a city.

Although some terrorism can be state sponsored, the more difficult problem facing the United States and other target countries is the terrorism that follows from radical Islam without specific government sponsors. This means that, unlike the conflict with the Soviet Union in the half century after World War II, the new terrorists do not provide an adversary with whom to negotiate or against which to retaliate. The insights of Tom Schelling's Strategy of Conflict do not lend themselves directly to dealing with today's adversaries.

We do not know why radical Islam is spreading as it is or how long it will remain a major source of violence. Alan Krueger has shown us that the terrorists are not driven by their personal poverty. We understand that the leaders of Al Qaida are eager to replace the leadership in Saudi Arabia, Egypt and elsewhere. We know that the high oil prices are contributing to the funds that finance the new terrorism and the spread of its ideological underpinnings. But there is so much about the cause, nature, and financing of the Islamic jihad that we do not know.

Since I cannot begin to deal with all of these issues in the current brief paper, I will focus on the issue of institutional change and international cooperation indicated in the title of this session.

The two aspects of counterterrorism are (1) the gathering and analysis of intelligence about the activities of would be terrorists and (2) the interruption or prevention of such terrorist 
acts. For the United States, both aspects involve new institutions, new legal rules, and new forms of international cooperation.

Intelligence Gathering and Analysis. The operation of British intelligence is a useful place to begin because it provides an informative contrast to American experience. British intelligence has long been divided into two separate services: the MI5 (now known as the Security Service) does intelligence gathering and analysis within the U.K. while the MI6 (now called the Secret Intelligence Service) deals with intelligence activities in the rest of the world.

Until the attacks in Britain by the radical Islamists, the MI5 had concentrated in recent decades on the activities of the Irish separatists while the MI6 dealt with foreign powers, primarily the Soviet Union and the affiliated communist organizations in other countries. The primary job of these intelligence services is still to understand the activities and plans of potential terrorists by infiltrating the terrorist organizations and the communities from which they come and by recruiting others to report on these groups. These forms of direct human intelligence gathering are supplemented by electronic surveillance and other forms of acquiring information. An important activity of these intelligence services is to analyze the information gathered in these ways in order to anticipate specific terrorist acts and to develop ways of reducing all terrorist activities and terrorist recruiting. Although the MI5 does not have "police powers” of arrest, it collaborates with the British police authorities (Scotland Yard) when such arrests are needed.

The explosion of Islamic terrorism in Britain led to a reform of the MI5 and MI6. The MI5 shifted its intelligence gathering from the Irish community to Muslim groups and 
individuals, especially those from Pakistan. Although this required infiltrating new groups and recruiting new sources, the basic MI5 tasks of human intelligence gathering and analysis did not have to change. This made the British task much easier than the reforms in the U.S. intelligence community that I will describe below.

The MI6 shifted its activity radically to focus on what is happening in Pakistan and other places where British terrorists are trained. Instead of being an intelligence agency with its own agenda, the MI6 became the producer of information for the MI5. Although this was a major change in MI6 activities that some insiders may have seen at the time as reducing its relative status, the importance of the Pakistan training and the broader links of the terrorists with Pakistan made this transformation necessary and its new role one of critical national importance.

This British experience provides a useful comparison to the experience of the United States where intelligence activities are divided between the FBI and the CIA. Until the 9/11 attacks there was relatively little official concern about the possibility of terrorist acts against the United States. The 9/11 attacks changed that and led to a major increase in CT activity, particularly by the FBI. The need for a new counterterrorism role for the FBI is the major challenge for institutional design in dealing with terrorism in the United States.

Before focusing on the FBI, it is useful to understand the broader scope of the U.S. intelligence community. Since its founding in 1947, the CIA has had primary responsibility for human intelligence gathering (i.e., by infiltration, the recruitment of others, mail intercepts, etc..) on intelligence targets outside the United States, particularly in the Soviet Union. The CIA also received and analyzed information collected by satellite interception of foreign telephone communication (the "signal intelligence" of the National Security Agency), by the satellite 
photography of the National Reconnaissance Organization, and by other parts of the intelligence community. All of this was restricted to the activities of foreigners. The CIA is not allowed to collect information on U.S. citizens, green card holders, and other persons in the United States.

The Federal Bureau of Investigation. The FBI is the primary law enforcement organization of the federal government. It is responsible for investigating a wide range of criminal violations of federal law (including kidnaping, bank robberies, narcotics violations, child pornography and certain hate crimes) as well as dealing with terrorism, industrial espionage, and counterintelligence. The Special Agents of the FBI have the power to arrest and work with the local federal attorneys general who prosecute the resulting criminal cases. As this description indicates, the FBI is and has been very different from the British MI5. The FBI's focus has been on the capture and punishment of criminals after crimes have been committed rather than on the prevention of unwanted acts.

The FBI is organized into 56 local offices around the country. Although each office reports to FBI headquarters in Washington, the local offices have historically been relatively independent because the crimes with which they dealt were local. Until recently, the work of the FBI did not use a group of analysts similar to those of the CIA and of the MI5 since the FBI's Special Agents drew their own inferences as they pursued individual criminals. There was only a small analytic group at FBI headquarters that could in principle analyze information forwarded from the field.

The FBI agents were typically recruited among former law enforcement and military personnel, as well as lawyers and accountants whose skills were helpful in dealing with white 
collar crimes. All FBI recruits have to pass relatively rigorous physical tests (running, chin ups, etc) that were appropriate to their work as law enforcement officers.

Counterterrorism was a small part of the FBI's work prior to nine-eleven. The law governing FBI activities also limits CT work to actions against individuals who are believed to be acting on behalf of a foreign power. Although wiretapping and other forms of electronic surveillance are readily authorized by ordinary courts for FBI use in criminal investigations, their use in CT investigations requires specific authorization by a special federal court, a process that involves substantial red tape and can involve long delays.

After the attacks of nine-eleven, new legislation and presidential orders made CT a primary responsibility of the FBI. The government substantially increased the FBI's budget for this purpose, created new positions in FBI headquarters to oversee CT activities, and required each local FBI office to create an intelligence gathering and analysis group.

But increased dollars, new leadership positions, and some organizational changes in the local offices did not automatically change the operation of the FBI on the ground. The shift from traditional criminal work to CT requires a major change in the culture of the organization, a shift from arrest and prosecution after a crime has been committed to the gathering of information and analysis designed to prevent terrorist acts before they happen. The FBI Special Agents doing CT work collect intelligence and task "sources" (i.e., ask individuals who are not government employees) to collect intelligence, a very different activity than the overt police work of criminal investigation and prosecution.

This creates a difficult problem for FBI personnel management. FBI Special Agents who do criminal work can be evaluated and promoted on their record of arrests and convictions. In 
CT work, the primary product is information and analysis rather than arrests and convictions, making it far more difficult to measure the productivity of individual Agents and to compare the performance of Special Agents doing counterterrorism with the performance of those doing criminal work.

For FBI Agents with many years of experience doing criminal work, the shift to CT required a fundamental reorientation of daily activities and of how the agents judged their own performance. For men accustomed to the gun-carrying police work of arrests, the shift to intelligence gathering may seem to be a very tame activity even though its contribution to national security is greater than what they had done in their criminal work.

None of this cultural change was needed in Britain's MI5. The members of the MI5 only had to shift their focus from Irish terrorists to Muslim terrorists. There were no doubt difficult practical issues in infiltrating a new population group, especially one that is ethnically so different from the MI5 staff. But the culture of recruiting sources in the terrorist base community and tasking those sources to collect information was a familiar one. The MI5 also had the tradition of a strong analytic group whose task was to integrate the intelligence collected in the field.

For the FBI, achieving the necessary cultural change requires significant institutional changes. These changes are a work in progress. A visit to the FBI's recruiting web site now shows a new emphasis on counterterrorism careers, with separate career paths for criminal, CT, and cybercrime. Recruiting goes beyond the ethnic and professional groups that previously produced FBI Special Agents. The training program that Special Agents receive gives more attention to problems of terrorism than it did in the past. The principle criticisms raised by 
Richard Posner and others is that these changes have not gone far enough, leaving the FBI with a bias in favor of criminal work and a staff that prefers criminal work to CT investigations.

The new CT responsibilities of the FBI also required the creation of a group of analysts who can interpret the evidence collected by the special agents and who can use their analytic product to direct additional investigations. At first, the individuals assigned to these positions were previous clerical staff and low level administrators of the FBI. They lacked the training and skills to do this important work. Over time, the FBI has been recruiting a more qualified group of analysts, although critics note that the training of these analysts needs to be substantially strengthened.

Communication and Coordination within the Intelligence Community In addition to changing the culture to give greater value to CT work and strengthening the personnel by new recruiting and training, the FBI (and the intelligence community more generally) had to create institutions to increase communication within the intelligence community. The official 9/11 Commission concluded that the failure of the intelligence community to predict and therefore prevent those attacks despite scattered recognition of suspicious activity pointed to the failure of communication across FBI offices and between the FBI and other parts of the intelligence community. That lack of communication was not a problem when the FBI's activity focused on local crimes but was inappropriate for its new CT mission.

Five new institutions were created to increase communication and to coordinate CT operations. First, the Department of Homeland Security (DHS) was created in 2003 to combine a variety of existing agencies that collect information and that take actions relating to terrorism 
and CT, including the immigration service and the Coast Guard. Second, the National Center for Counterterrorism (NCTC) was created in 2004 to integrate and analyze on a real time basis the information dealing with terrorism that is collected by all parts of the intelligence community. Staff from the FBI, CIA, and other intelligence agencies sit at the NCTC facility where they share information reports and have access to the information generated within the separate intelligence organizations. A principal function of the NCTC is to perform integrative analyses of the information that is collected. Third, also at the national level, legislation enacted in 2004 created a new organization (the Office of the Director of National Intelligence) to coordinate the entire intelligence and counterterrorism activity of the government, headed by a Director of National Intelligence. The NCTC is part of that Office.

Fourth, there is now a Joint Terrorism Task Force (JTTF) in each of the 56 FBI local areas. The JTTF provides a physical location and organizational structure that brings together FBI agents, CIA agents, local police officers, members of the Defense Intelligence Agency and others to share current intelligence information collected in that geographic area. And, fifth, the federal government has mandated and subsidized each state government to create a Fusion Center that combines state police, local police, and members of the intelligence community to coordinate information and actions on terrorism, criminal activities, and major natural disasters.

As a result of these new institutions there is undoubtedly much greater coordination of information and a greater sense within the police organizations as well as the intelligence community of the importance of counterterrorism activities.

International Cooperation. Although there is the risk of self-radicalized terrorists in the United 
States who are inspired by the Islamic jihad, the primary terrorist threat to the United States now comes from abroad. Similarly, within Britain, Europe, and the Middle East the terrorists either come from abroad or are local residents who have gone abroad for training.

It is therefore clear that effective counterterrorism requires international cooperation. Newspaper reports indicate that such cooperation is now actively pursued. The intelligence services of Britain, the United States and Pakistan cooperated to prevent the planned simultaneous bombing of airplanes traveling from London to New York. The U.S. and Russian intelligence services coordinated the arrest of an individual who was attempting to sell fissile material. Additional reports involving virtually all of the major countries can be found in news stories during just the past two years.

Two things stand out about the nature of this international cooperation. First, there is no formal organization through which this cooperation occurs. Information sharing is done on a bilateral and multilateral basis among the individual national intelligence agencies. Second, close cooperation with the United States occurred even by governments that in public were very critical of U.S. policy in Iraq and elsewhere.

It is interesting therefore to ask what it is that drives this close international cooperation in counterterrorism. I believe that three things have been essential to the ability of the U.S. to get such close cooperation from foreign intelligence services. The first of these is the selfinterest of all the cooperating countries. Each country can gain from trading information about potential terrorist threats. This is very different from attempts at cooperation in military activities in Afghanistan or Iraq where national self interest is less obvious to other countries or in discussions about the use of economic sanctions which countries resist because of potential loss 
of export sales. Second, the United States has superior space-based technology for surveillance of electronic communication by voice and internet and for photographic reconnaissance. Other nations need to cooperate with the United States in order to get the information that only we can obtain in these ways. And, third, the collaboration among intelligence services is generally done without the public visibility that accompanies attempts at military and diplomatic activities through organizations like the United Nations.

Terrorism is unfortunately likely to be one of the major problems facing the United States and other nations in the years ahead. Continued progress in strengthening counterterrorist organizations within the United States and cooperation in counterterrorism among allies will therefore remain one of our key national priorities.

December 2007 